\title{
Mars w wieku miodowym. Retoryka wojny w odach Macieja Kazimierza Sarbiewskiego
}

Elwira Buszewicz 
nAPIS Seria VII 2001

\section{Elwira Buszewicz}

\section{Mars w wieku miodowym. Retoryka wojny w odach Macieja Kazimierza Sarbiewskiego}

\section{Skoro wszystko już powiedziano}

1 Może się wydawać, że będzie to kolejna historia z serii „Znacie? - to posłuchajcie”. Czy nie wystarczyłoby dla potrzeb tego tematu przywołanie kilku najbardziej znamiennych ód poety z Sarbiewa i opatrzenie ich komentarzem nie wykraczającym zbytnio poza fragmenty przedmowy do najpełniejszej dotąd polsko-łacińskiej edycji jego wierszy? Autor tego wstępnego szkicu ${ }^{1}$ przedstawił pokrótce zwięzły zarys interesujących nas zagadnień, umieszczając je w kontekście „inwencji tematycznej liryków Sarbiewskiego”. Wskazał na doniosłość humanistycznego oddziaływania dworu papieża Urbana VIII i przełomowe znaczenie okresu rzymskiego oraz panegiryku Aureum saeculum dla kształtowania się indywidualności twórczej poety. Zwrócił uwagę na silnie obecne w wierszach Sarbiewskiego stereotypy „pobudek” do antytureckiej krucjaty oraz swoiste tu „miejsca sarmackie” — laudację wiktorii chocimskiej z 1621 roku i propagowanie mitu Polski jako „przedmurza chrześcijaństwa”. Uwydatnił wreszcie perswazyjność i apelatywność liryki chrześcijańskiego Horacego, przejawiającą się w retorycznej strukturze ód i propagowaniu wzorców osobowych militis Christiani. Moglibyśmy więc na tej podstawie nakreślić sobie pewien uproszczony obraz zagadnienia - nie mielibyśmy też wątpliwości, że wiąże się ono ściśle $\mathrm{z}$ tradycją retoryczną; powinno to być zresztą oczywiste dla każdego, kto chociaż raz zetknął się $\mathrm{z}$ traktatem Charaktery liryczne, czyli Horacjusz i Pindar, w którym mowa (w sensie genologicznym) traktowana jest jako uniwersalny model piśmiennictwa, a zatem również utwory liryczne podlegają klasyfikacji w zależności od tego, jak realizują poszczególne genera dicendi.

1 Zob. M. Korolko, Sarbiewski i jego Liqki, w: Mathiae Casimiri Sarbievii „Lyrica...”- M. K. Sarbicwski, Liryki oraz „Droga rzymska” i fragment „Lechiady”, tł. T. Karyłowski TJ, opr. M. Korolko, współudz. J. Okoń, Warszawa 1980 (dalej: TK z paginacją w nawiasach), s. XXXIII-XXXVI. Pozostałe przckłady wierszy (ozn. - E. B.) - na podstawic części łacińskicj tego dwujęzycznego wydania. 
2. Spróbujemy mimo wszystko problematykę tę nieco wzbogacić. Mamy przecież świadomość, że od czasu pojawienia się $\mathrm{w}$ druku warszawskiego wydania upłynęło już lat z górą dwadzieścia, że od tego czasu przybyło nowych spojrzeń na osobowość twórczą Sarbiewskiego, owocujących konkretnymi publikacjami, których lektura, a także uważne czytanie samych liryków we właściwym kontekście, każe unikać naiwności i uproszczeń i wyznaczyć nowe horyzonty badawcze.

3. Okaże się wówczas, że taka, a nie inna obecność tematyki wojennej w pieśniach naszego poety i wszelkie retoryczne klisze użyte dla jej realizacji wiążą się nie tylko z intelektualno-religijną formacja albo z duchem czasów, ale przede wszystkim poświadczają (pozwolę sobie tu użyć frazeologii tytułu książki Marii Cieśli-Korytowskiej o Słowackim) „mityczną strukturę wyobraźni” poety. Powtórzmy zatem: wyobraźnia poetycka Sarbiewskiego, wyznaczająca sferę retorycznej inwencji, wyrasta zdecydowanie z szeroko rozumianego mitu. Mitu wyznaczającego syntetyczną czy raczej synkretyczną przestrzeń zachodzących na siebie kręgów tradycji hebrajskiej, pogańskiej i chrześcijańskiej. Nie miejsce tu, by się zastanawiać, na ile tę mityczną strukturę ukształtowały jakieś jednostkowe dyspozycje charakterologiczne, a na ile zaś u jej podstaw legła jezuicka humnanitas, na której rolę jeszcze na pewno zwrócimy uwagę. Inne - niebagatelne — rzutują z kolei także na sferę elokucji — nigdy dość sprawdzania, czy wystarczająco doceniamy wpływ obrazowania, metryki i leksyki wenuzyjskiego mistrza (i szerzej - pogańskiej Latinitatis) na Muzę chrześcijańskiego Horacego. Tym sposobem stajemy wobec całkiem obszernego kompleksu wzajemnie powiązanych zagadnień, które z konieczności musimy tu ograniczyć do nieco impresyjnych szkiców.

\section{Aureum saeculum: tęsknota za utraconą harmonią}

1. Jak „wiek złoty” ma się do wojny? Alternatywnie. Jedno wyklucza drugie. Konflikty zbrojne, jeśli wierzyć poetom, pojawiły się dopiero w wieku miedzianym, zaś ich eskalacja ponad miarę przyzwoitości, powodująca zanik poczucia bezpieczeństwa, to zdobycz wieku żelaznego. Warto przypomnieć kanoniczną wersję Owidiusza:

Jeszcze nie opasały miast urwiste wały, nie znano prostych trombit ni wygiętych miedzianych rogów, nie było hełmu i miecza, a nie znając broni ludzie beztrosko zażywali miłego wypoczynku. (...) Potem nadszedł wiek trzeci - miedziany. Gwałtowny, porywczy do broni. A jednak nie zbrodniczy. Ostatni wiek - żelazny. (...) Zjawiło się na świecie okrutne żelazo i okrutniejsze od żelaza - złoto. Nadeszła wojna, która posługuje się jednym i drugim, i potrząsnęła mieczem w skrwawionej dłoni. Ludzie żyją z grabieży, gospodarz boi się gościa, teść lęka się zięcia, nawet brat rzadko kocha brata. Mąż grozi śmiercią żonie, a żona mężowi, okrutne macochy warzą zółte tojady, syn przyśpiesza zgon ojca. Miłość rodzinna legła w pyle, dziewicza Astrea, ostatnia z bóstw, opuszcza ziemię we krwi skąpaną ${ }^{2}$.

\footnotetext{
2 Owidiusz, Metamorfozy, tł. A. Kamieńska, S. Stabryła, opr. S. Stabryła, Wrocław 1995 (BN II 76), s. 10.
} 
2. Mit wieku złotego obecny jest w literaturze europejskiej i polskiej w sposób szeroki i złożony. Istotę i genezę owej obecności zwięźle przedstawił współczesny badacz tego zagadnienia:

\begin{abstract}
W micie wieku złotego tradycja Śródziemnomorza zdeponowała przeświadczenie o tym, że w czasach początku panowało dobro i szczęście, że tedy skarlałe pod każdym względem pokolenie współczesnych nie wytrzymuje porównania z generacją pierwszych ludzi. Idea ta (...) wyraża (...) namiętną dezaprobatę dla stanu, do jakiego stoczył się świat w wyniku długiego procesu degradacyjnych zmian. (...) W konsekwencji, jak to wyraził H. Levin, wiek złoty jest tym wszystkim, czym wiek współczesny nie jest ${ }^{3}$.
\end{abstract}

Poeta posługujący się topiką wyrastającą z tego mitu wcale zatem nie musi się odznaczać jakąś optymistyczną wizją dziejów i entuzjazmem dla chwili bieżącej. Przeciwnie - to na ogól laudator temporis acti, przekonany, że żyje w epoce zmierzchu zepsutego świata, pośród skarlałych fizycznie i moralnie ludzi. Jeśli nawet wiara w powrót tych złotych lat, wpisana w przeświadczenie o cykliczności czasu, rodziła panegiryczne zastosowania takiego obrazowania, datujące się od Maronowej IV Eklogi, utwory takie raczej wyrażały tęsknotę do lepszych czasów niż entuzjastyczne doświadczenie. Na to wszystko nakładały się jeszcze chrześcijańskie reinterpretacje mitu wzbogacone biblijną konotacją raju ziemskiego czy mlekiem i miodem płynącej Ziemi Kanaan oraz wizjami mesjańskiego pokoju z Księgi Izajasza (na przykład Iz 11) czy innych proroków Starego Testamentu. Trochę inaczej jest z VI księgą Eneidy, gdzie Wergiliusz zdecydowanie określa czasy Augustowskie jako powrót czasów Saturna.

3. Maciej Kazimierz Sarbiewski najchętniej podejmuje taką właśnie, „zdegradowaną” panegirycznie, topikę wieku złotego, wiążąc jej nastanie z pontyfikatem Urbana VIII. Na pozór jest to entuzjazm dla mitu odradzającego się w postrzegalnej rzeczywistości: świadczy o tym obszerny poemat Aureum saeculum, jakim poeta-jezuita zalecał się poecie-papieżowi. Oto wraca na ziemię dziewica Astrea, czyli Iustitia, a więc będzie panować Zgoda, znikną wojny, zbrojne zamieszki, lęki i wściekłe szaleństwa. W podobnej tonacji i w klimacie nawiązującym silnie do IV księgi Eklogi, ale i do topiki Hezjoda i Owidiusza, utrzymana jest $L y r$ I 1. Pieczętuje ona czasy błogiego pokoju, upamiętniając pokonanie przez siły chrześcijańskie wojsk Gabora Pethlema. Ale już tu możliwy jest dystans: słowa otwierające tom liryków Sarbiewskiego, a zarazem tę właśnie odę Iam minae saevi cecidere belli - to nieco zmieniony cytat z Seneki, z tragedii Thyestes, gdzie chór starców chwali pokój, jaki nastąpił po pozornym pojednaniu Thyestesa i Atreusa, lecz jednocześnie wątpi w jego trwałość ${ }^{4}$. Czy zatem - jak podejrzewa współczesny badacz poezji Sarbicwskiego — „i Urbanowy wiek złoty miałby podobnie wątpliwą jakość?”. W Ważdym razie wiąże się z nim pewna umowność! W Lyr. III 15 pojawia się szczególnie wytworny koncept, gdzie wiek złoty nazywany jest miodowym - przez metonimiczne przywołanie czasów „miodem płynących” oraz sieć skojarzeń symbolicznych (miód = pożytek), heraldycznych (pszczoły w herbie rodu

${ }^{3}$ D. Śnicżko, Mit u'ieku zlotego u' literaturze polskiego renesansu. Wzory-warianty - zastosow'ania, Warszawa 1996, s. 9. Zob. też: E. Micletinski, Poetyka mitt, tł. J. Dancygier, Warszawa 1981, s. 276; H. Levin, The Myth of the Golden Age in the Renaissance, London 1970; R. Caillois, Żwiol i lad, wyb. A. Osçka, tł. A. Tatarkiewicz, Warszawa 1973.

4 Zob. P. Urbański, Między ignacjanizmem a neostoicyzmem, w: idem, Theologia fabulosa. Commcntationes Sarbievianae, Szczecin 2000 (Rozprawy i Studia nr 376), s. 101.

5 Ibidem, s. 103. 
Barberinich) oraz tonację kolorystyczną (złotawo-płową barwę wiosny, a zarazem miodu i miododajnych owadów). Świadomości literackiej utopii może dowodzić paradoks zamieszczonyw tekście ody jako pytanie:

Czemuż to mozolnymi biedzicie się loty,

Umorusane w łąk trawie,

$\mathrm{W}$ gorliwej trudzie roboty,

Skoro pod Barberinim, rządzącym laskawie,

Miodowe lata nastają,

Waszej zgotowane sławie?!

(w. 7-12, TK 231)

Dotykamy tu istoty barokowego konceptu, opartego na retoryce iluzji, czyli próbach uwiarygodnienia i udosłownienia metafory. Poeta zdaje sobie sprawę z tego, że poetycki mit i świat wyobraźni zderzają się z prawami rzeczywistości: mimo że nastał wiek miodowy, pracowite owady nadal muszą zbierać nektar, poeci-pszczoły muszą pisać panegiryki, a papież z pszczołami w herbie musi walczyć o zachowanie pokoju w chrześcijańskim świecie.

4. Okazuje się bowiem, że bliższa mentalności Sarbiewskiego jest wizja świata starzejącego się, gnuśnego i upadającego; Mars zbiera swoje żniwo i w miodowym wieku, podobnie jak śmierć w Arkadii. Podstawowym zagrożeniem dla jedności łacińskiej Europy wydaje się potęga turecka. Papież, jedyny gwarant dalszego trwania historii, praesidium orbis, jak świadczy między innymi $L y r$ I 10, ma być przywódcą antytureckiej kampanii, a także pośrednikiem w konfliktach wewnątrzchrześcijańskich; ma do spełnienia misję, która wymaga jeszcze długiego życia. Zatem wizja Nowej Rzeczywistości wpisuje się i tutaj w poetykę proroctwa i tęsknoty za utraconą harmonia mundi:

Niebawem, jeśli spełni się wizja mej

Nadziei dobrej, do twych upadną stóp

Narody wielkie i królowie.

O ginącego podporo świata,

I opiekunie! Radą i mocą swych

Podtrzymaj ramion upadający wiek,

Walczących wodzów zbaw od śmierci,

Państwa od ruin, upadku, klęski.

I jak najpóźniej dołącz do grona gwiazd

$\mathrm{Na}$ jasne niebo. Nie spiesz się do tych uczt,

Na których wśród życzliwych niebian

Będziesz ambrozję mieć za swój pokarm.

Niech jak najpóźniej po swoim Ojcu Rzym

Zapłacze, niech się jeszcze Kwiryci twą

Napasą cnotą, i szlachetna

Kuria, i kardynałowie strojni 
W purpurę. Niech się oprze na tobie świat

$Z$ radością i oddaniem na długi czas.

Remusa lud i miasto całe

Kochaj bezpiecznie. Choć niebo winno

Dać ci nagrodę, nie spiesz się, by ją wziąć

Od Boga. Odłóż gwiazdy na potem, aż

Poskromisz Betys, Tag, Loarę

I Eridanos kipiący wojną.

Aż Hebros rzuci w hołdzie u siedmiu wzgórz

Złamane rogi, w pętach przywiedzie ci

Tyrana Grecji, na żałosny

Koniec i hańbę zuchwalstwa jego (...)

(w. 49-76, tł. E. B.).

Mitologizacja roli Urbana VIII jako zbrojnego przywódcy chrześcijaństwa, jaka dokonała się pod piórem poety z Sarbiewa, jest tym bardziej widoczna w świetle słów współczesnego nam historyka, który stwierdza jasno:

Zainaugurowany w 1623 roku pontyfikat Urbana VIII oznacza koniec rzymskich roszczeń do kierowania wojnami religijnymi,

papież bowiem:

...bardzo szybko kieruje swoją uwagę ku celom bardziej żywotnym i doczesnym, rezygnując z fikcji wojny religijnej na rzecz konfliktu o charakterze czysto politycznym i w rzeczywistości zrzeka się statusu przywódcy obozu 6 .

\section{Retoryka krucjaty: walka $z$ islamem i obraz Turka}

1. Na temat tej części liryki sarmackiego Horacego, jakąjest agitacja na rzecz wojny z Turkami, powiedziano stosunkowo dużo. Zwrócono uwagę na rozmaitą motywację owych „ekscytarzy” czy pobudek, na przykład w kierunku odzyskania prowincji greckich, ważnych dla poety jako kolebki śródziemnomorskiej cywilizacji ${ }^{7}$. Retoryczna argumentacja tych poetyckich apeli oparta była nieraz na błyskotliwych konceptach, przejawiających się na przykład w wizjach Grecji jako krainy bogatej, kuszącej obfitością potencjalnych zdobyczy, albo w tendencjach imperialnych chrześcijańskiego Zachodu, któremu do radosnego sprawowania władzy brakuje jeszcze jedynie... Wschodu. Mamy tu do czynienia z wieloaspektową metaforyką łączącą kategorie przestrzenne

7 Zob. M. Korolko, op. cit., s. XXXIII. 
i czasowe, z polisemantyczną, przede wszystkim wartościującą alegorystyką jutrzenki i zmierzchu, dnia i nocy, światła i ciemności:

Powstańmy. Wszystkich wzywa zaranie dnia

I Febus z Indii, Febus, lecz wszak nie nasz

On jest, Kwiryci! Łacińskiemu

Światu Wschód służbę swą wypowiedział!

Czyż całe niebo musi o brzasku dnia

Nieść Ottomańską groźbę? O jaki wstyd!

Zachodnie tylko i zmęczone

Słońce Hesperii służyło będzie

Latynom, gdy szkaradny zapada zmierzch?

Powstańmy. Do Gangesu dodajmy Tybr,

Do Nocy Brzask, do Tagu - Baktrę,

Ojtę i Paros z Kadyksem złączmy

(Lyr. I 8, w. 41-56, tł. E. B.).

Najbardziej chyba przejmującą z owych „pobudek” jest Lyr. I 16. Jako że „pobudka” zakłada zwrot do „uśpionych” — Sarbiewski realizuje ten postulat w podwójnym sensie: przemawia do zdegenerowanych i gnuśnych współczesnych, zaś pośrednio wzywa z grobów dawnych rzymskich bohaterów, aby pokonali siły tureckie. Prędzej bowiem niż ich zniewieściali następcy powstaną umarli, i raczej u nich można się spodziewać efektów retorycznego permovere:

Wielki Pompeju, przyzywają ciebie

Wielkie Grobowce Azji. Ty, Cezarze,

Masz przeciw sobie miecz, ogień, kajdany

I strzały Traków.

Baktra przeniosła już swoje obozy,

Dźwięk rogu Marsa przeraził obłoki:

Już straszne wieści konna jazda niesie,

Głucho brzmi rżenie.

Powstań; w galopie Med kopytem trąca

Urnę, gdzie drzemiesz. Czy możesz w tym grobie

Leżeć spokojnie albo śnić beztrosko

Sny o potędze?

Idźcie, powtórzcie swe zwycięskie boje;

Idźcie, Rzymianie. Niech się wam podoba

Ze sławnych odrzwi zdjąć broń, a na głowę

Hełm wdziać zwyczajny

(w. 29-44, tł. E. B.). 
2. W antytureckiej liryce Sarbiewskiego mieści się też, jak to pokazano, upowszechnianie ideologii geograficznego przedmurza, czego elementem były laudacje wiktorii chocimskiej 1621 roku i wyolbrzymianie roli udziału w niej Władysława IV Wazy, wtedy jeszcze królewicza, co przyczyniło się do ugruntowania w Europie opinii o nieprzeciętnych talentach tego władcy ${ }^{8}$. Dotykamy tu frazeologii związanej z ideologią przedmurza ${ }^{9}$, co wiąże się z całą tradycją turcyków ${ }^{10}$; jednak te stereotypy retoryczne sięgają początków chrześcijańskiej wojny z islamem czasów krucjat. Bernard z Clairvaux usankcjonował świętą wojnę:

8 M. Korolko, op. cit., s. XXXIV.

${ }^{9}$ Zob. m.in.: J. Tazbir, Polskie przedmurze chrzésicinniskiej Europy. Mity a rzeczyuistość historyczna, Warszawa 1987, passim (tamże o twórczości Sarbicwskicgo wzmianki na s. 55, 59). Na s. 5 czytamy:

„Termin przedmurze należy do pojęć, które odegrały istotną rolę w rozwoju polskicj świadomości historycznej. WXVI i XVII stuleciu odpowiadał on konkretnej rzeczywistości, związancj z geopolitycznym położeniem Rzeczypospolitcj Obojga Narodów (...). Sano wyliczenic tytułów prac, rodzimych i obcych, w których od połowy wicku XV poczynając, pisano o Polsce jako o murze, płocic, wale, tarczy, ścianic czy twicrdzy chrzcścijaństwa, zajçłoby dobre kilkanaścic stron. Przcz długi czas stosowano głównie łacińską terminologię, a pierwsze próby jej spolszczenia przychodzą stosunkowo późno. To samo dotyczy pojawienia się słowa antemurale w rodzimcj wersji, a więc jako przedmurze. Pojęcic to występuje dwukrotnic w Starym Testamencic (...) Dopicro w przckładzic (...) Jakuba Wujka (1599) pojawia sį̨ znany nam dobrze termin: "będzic w nim położony mur i przcdmurzc" (Izajasz), «i płakało przedmurze i mur społem rozwalony jest» (Treny [Jeremiasza]). (...) Slowo przedmurze nic od razu jednak zyskało w polszczyźnic przenośny sens, skoro w wydanym w kilkanaścic lat po tłumaczeniu Wujka słowniku Grzegorza Knapskicgo (1621) pojçcic to posiada wyłącznic materialne znaczenic".

Warto notabene nadmicnić, że pojęciom „przedmurza” i „Rzeczypospolitcj” poświçca siç ostatnio wicle uwagi takżc od strony leksykalno-scmantyczncj, szczcgólnic ich swoistej „tożsamości kulturowej” — a co za tym idzic, niemal nieprzetlumaczalność na język wspólczesncj kultury Zachodu. Zob. T. Bałuk-Ulewiczowa, Authors and Authorities: Non-Superimposable Images of the Classics in the European National Traditions and Untranslatablity, PASE Conference, April 2001 (druk matcriałów z tcj konferencji przygotowuje Wydawnictwo Uniwersytctu Jagicllońskicgo). Autorka zwraca przy sposobności uwag̨ na wicle istotnych szczc gółów historycznych, między innymi na obecność ideologii przedmurza także w tradycji węgicrskicj (do bitwy pod Mohaczem) oraz na jej raczcj oficjalny i inspirowany z zewnątrz charakter przed XVI-XVII stuleciem:

„The historians of literature who have addressed the subject, Sante Graciotti and Wiktor Weintraub, confirm the surprising observation "that in $16^{\text {th }}$-century Poland the antemurrale myth was neither widespread nor popular; and that it had been first introduced in the late $15^{\text {th }}$ century' by foreigners, the humanist éminence grisc Filippo Buonaccorsi Callimacho and a muncio representing Pope Pius II (Enea Silvio Piccolomini), in rather futile attempts to involve the Poles in an anti-Tirkish league. While the historians Henryk Samsonowicz and Janusz Tazbir trace the Polish tersion of the myth back to 1319 and a petition to the Pope, they concede it was not an original Polish idea: the diplonatic phraseology was ar'ailable in earlier Hengarian, Cypriot, and Vénctian models. It secms therefore that the myth of the Polish bulw'ark was not developed and disseminated tintit the $17^{\text {th }}$ century, when relations with Turkey were changing, the Polish State was growing feebler, and other foes were becoming more ominous. All the time, however, nomadic Tartars, the Grand Turk's sometimes undisciplined, sometimes deliberately incited vassals, u'ere making regular incursions of Poland's south-eastcrn border, ureaking havoc on the land".

11 Nalcży tu odnotować w picrwszcj kolcjności dwie mowy Stanisława Orzcchowskicgo: De bello adversus Turcas suscipiendo... ad equites Polonos oratio, Kraków 1543, a także Ad Sigismundum Poloniae regem Turcica secunda, Kraków 1544. Charakterystyczna jest zwłaszcza picrwsza mowa, już od $15+3$ roku znana w przckładzic polskim, Ksiqżki Stanisława Orzechowskiego o ruszeniu ziemie polskiej przeciu Turkowi z lacińskiego jęzүka na polski urytożone każdemu rycerskiemu czlouriekou' pożyteczne, gdzie widać już grunt i pożywkę dla Pié́ni o spustoszeniu Podola przez Tataróu'J. Kochanowskicgo - np.: "Jcsli więc na inszy czas będzicm odkładać tę obronę a pomoc samsiadom naszym, boję się, bysmy tego barzo nic żałowali a z płaczem nie mówili to, co głupi po szkodzic zwykli mówić: «A com ja wicdział?» (...) Tak też my, panowic Polacy, póki nam jeszcze Turck gardł nic pobrał, póki jeszcze nie chodzimy w jego pęcicch, póki ta Korona w całości kwitnic, pókismy jeszczc ludzic nic pomordowani, póki jeszczc o Polakoch dobrzc trzymają — pomyślmy o tym, jakobysmy przy gardłach, wolnościach a majętnościach naszych zostali" (cyt. za: Proza polska u'czesnego rencsanst 1510-1550, opr. J. Krzyżanowski, Warszawa 1954, s. 423). 
...śmierć poganina to chwała chrześcijanina, gdyż jest dla chwały Chrystusa (...)

Żołnierz Chrystusowy (...) zabija ze spokojnym sercem, a jeszcze ze spokojniejszym umiera ${ }^{11}$.

Nie powinny więc szokować (choć muszą) podniosłe wezwania poety-jezuity do rozlewania krwi muzułmańskiej na pohańbionych mogiłach przodków, jak na przykład w Lyr. I 20:

Kto teraz zechce podjąć pomyślny bój,

Przebłagać duchy przodków? Czy jakaś dłoń

Zabije dzielnych Muzułmanów,

U grobu ojców ofiarę złoży?

(w. 37-40, tł. E. B.).

3. Z retoryką krucjaty wiąże się też kwestia obrazu Turka. Jak zauważyła Marina Ciccarini w pracy poświęconej wprawdzie XVI-wiecznym dziennikom podróży na Wschód - jest to często przywołanie ambiwalentne, z jednej strony zdeterminowane religijnie i jako takie nacechowane niechęcią, z drugiej - niekiedy ulegające fascynacji tym, co odmienne, egzotyczne ${ }^{12}$. Poezja Macieja Kazimierza Sarbiewskiego także przynosi zdecydowanie negatywny obraz muzułmanów, aż do dehumanizacji widzenia, a niekiedy swego rodzaju zdumionego podziwu. Nazywając tu i ówdzie Turków „psami”, mieści się w świecie wyobrażeń Bernarda z Clairvaux. Pewnej fascynacji dzikością dowodzi oda III 20, poświęcona śmierci bliżej nieznanego rycerza Wiśniowskiego „którego serce, gdy zginął za ojczyznę, Turcy w barbarzyński sposób podzielili między siebie i pożarli”:

\author{
Zaciekli Tracy mieczami greckiemi \\ Pierś otworzyli męża, żeber kleszcze \\ Rozcięli z furią i klęcząc na ziemi \\ Serce i trzewia krwawe, ciepłe jeszcze, \\ Jak zwierz, co kłami swą zdobycz rozdziera, \\ Pożarli, szarpiąc chciwie na kawały, \\ Jednak podniosłej duszy bohatera \\ Wchłonąć nie mogli, ni wydrzeć mu chwały (...).
}

(w. 17-24, TK 249)

11 Bernard z Clairvaux, De laude novae militiae, rozdz. 3: „In morte pagani Christianus gloriatur, quia Christus glorificatur”; „Miles (...) Christi securus interimit, interit securior” (Sancti Bernardi Opera, vol. 3: Tractatus et opuscula, opr. J. Leclercq, H. M. Rochais, Romac 1963, s. 217); tł. pol. za: G. Minois, op. cit., s. 143, tamżc komentarz G. Minois: „Muzułmanie są 'naczyniami nieczystości', rządzi nimi diabeł. Jest tylko jedno rozwiązanie: eksterminacja. Zabijajcie! Zabijajcie! I sami dajcie sic̨ zabić, jeśli zajdzie taka potrzeba. Uczyńcie to dla Chrystusa (...). To straszne słowa, to chorobliwa apologia zabijania na wojnie. Widać tu doskonale, w jaki sposób walka duchowa i męczeństwo mogą doprowadzić człowieka o temperamencie fanatyka do pragnienia świętcj wojny".

12 Zob. M. Ciccarini, Il richiamo ambivalente. Immagini del Turco nella memorialistica polacca del Cinquecento, Bcrgamo 1991. Por. na przykład uwagi poświęconc zapiskom księcia Radziwiłła Sierotki (s. 150), gdzie autorka zwraca uwag̨ na oscylowanie postawy narratora między uprzedzeniami (dotyczącymi zwłaszcza "szalonych" i "nicrozumnych" Turków) a pokorą w przyjmowaniu wiedzy o egzotycznym świecie. Por. też s. 101, gdzie zwraca się uwagę na uwydatnienie przez Sierotkę „zwierzęcości” muzułmanów — „barbarzyńskich” nic w optyce złotcgo wieku, idcalizującej kultury prymitywne, lecz w kontekście zagrożeń dla świata chrześcijańskiego: nosicieli szaleństwa, chaosu, dzikości i zarazy duchowej, co stanowiło niebagatelne źródło lęku także w XVII-wiecznej Europic, spragnionej ładu społecznego. 
Mamy tu do czynienia zarówno z potępieniem muzułmańskiego barbarzyństwa, w którym gorliwy czytelnik Seneki widział z pewnością nową ucztę Thyestesa, jak i z rodzajem zdumionej fascynacji prymitywizmem i zwierzęcą dzikością — zresztą skłonność ludów Wschodu, zwłaszcza na przykład Tatarów, do jedzenia czegokolwiek na surowo, choćby świeżo zdechłego lwa, była przedmiotem fascynacji już w czasach Zygmunta Starego! ${ }^{13}$

\section{Przeciw wojnie domowej: w imię jedności chrześcijańskiej Europy}

...pestifera bella civilia; quae gravis et fortis civis et in re publica dignus
principatu fugiet atque oderit tradetque se totum rei publicae M. T. Cicero, De officiis, lib. I

1. W obronie jedności chrześcijańskiej Europy wobec wspólnego wroga wykorzystywane były przez Sarbiewskiego loci communes potępienia wojny domowej, obecne od dawna w szeroko rozumianej tradycji retorycznej, antycznej i nowożytnej łacińskiej, a także rodzimej, sarmackiej ${ }^{14}$. Skoro wizja jedności politycznej tak silnie wiąże się ze świadomością europejską Macieja Kazimierza Sarbiewskiego, wyznaczona, jak to przekonywająco pokazał Andrzej Borowski ${ }^{15}$, przez Latinitas i Christianitas, oczekiwać należy u poety jakiegoś poszerzenia strefy „ojczyzny”. Widać to zwłaszcza w odach rzymskich, adresowanych do papieża Urbana - ich „nadawcą” jest obywatel orbis Christiani. Ta przestrzeń staje się najistotniejszym odpowiednikiem szeroko rozumianego „domu-ojczyzny” — stąd możliwa tu retoryka wojny domowej dla konfliktów wewnątrz chrześcijaństwa, które powinno raczej zjednoczyć się wobec zagrożenia muzułmańskiego. Widać to wyraźnie w Lyr. II 23 (Do Niemiec objętych pożarem wojny domowej):

13 Interesującą wzmiankę na ten temat mamy w uwagach Joachima von Watt (Vadianus) do opisu Sarmacji Pomponiusza Meli. Komentator stwierdza, ze pewna ilość Tatarów znajduje siç stale na Zamku Wawclskim; najulubieńszą potrawa jest dla nich końskic miçso. Sam był świadkicm, jak wypatroszyli świcżo zdechłcgo lwa i spożyli, delcktując się wspaniałą ucztą i zapraszając do nicj zgromadzonych wokół widzów, podziwiających dzikość konsumentów: „Cum Cracoviae essem, leonem catulum, qui in aula tum forte mortuus erat, eviscerabant, celebrique devorabant convivio, adstantis etiam nobis et feritatem demirantibus, ut comessemus, invitatis"; cyt. za: Pistoriusz, Polonicae historiae corpus, t. 1, Basileac 1582, s. 159-160.

14 Zob. np.: Napomnienie polskie ku zgodzie do wszech krześcijanów wobec, a mianowicie do Polaków uczynione Stanisława Łaskiego z 1545 roku: „Dla tego dobry a krześcijański pan ma sį̨ strzec walki domowcj, a chować siç na nicprzyjacicla krzyża świętego, aby raczej ty rzeczy, bez których w wojszcze być nie może, bo ludzie wżdy nic są angeli, działy się na gruncie nieprzyjacielskim niz doma" (cyt. za: Proza polska wczesnego renesansu..., op. cit., s. 452).

15 Zob. A. Borowski, O świadomości europejskiej Macieja Kazimierza Sarbiewskiego, w: idem, Powrót Europy, Kraków 1999, s. 190-191: „Najważnicjszym wyznacznikicm europcjskości był wówczas chrystianizm, tj. christianitas, i to w formic kulturowcj najbardzicj wtenczas awangardowcj, jeśli można tak rzec, czyli christianitas jezuicka, po drugie — łacińskość kultury literackicj (latinitas) (...). Za trzeci wyznacznik europcjskości uznaję ścisłą wiçź pocty z instytucją szkoły i z wychowaniem, a także obecne w akcie twórczym poczucie obowiązku oddziaływania edukacyjncgo i wychowawczego poprzez poezję. Czwarty wyznacznik świadomości curopejskicj Sarbiewskicgo to (...) poczucic «północncj odrçbności» i zarazem dowartościowanej swoistości (...). Osobnym wreszcie i najścišlcj z "curopcjskością" Sarbiewskiego powiązanym zagadnieniem jest jego świadomość narodowa, czyli sarmatyzm". 
Na co się przyda w bratobójczej wojnie

Klęsk tyle ściągać na kraj nieszczęśliwy?

$\mathrm{Na}$ co się przyda krwią zlewać tak hojnie

Kwitnące niwy?

Mieczy, sposobnych na pohańców głowy,

Niech zawiść, Niemcy, nie dobywa sroga:

Oto wam cesarz w dłonie kładzie nowy

Oręż na wroga.

Oszczędny w gniewie, niechciwy oręży,

Dla wszystkich ludzki i uprzejmy społem,

Bez srogiej rzezi wasz cesarz zwycięży

Turka z Mongołem.

(w. 1-12, TK 169)

W dalszych strofach pieśni pojawia się wizja przyszłego pokoju, gdzie inwencja, łącząca proroctwa starotestamentowe z Horacjańską wizją wysp szczęśliwych, każe się dopatrywać ech szesnastej epody Wenuzyjczyka, a co za tym idzie - znów dość pesymistycznej wizji świata.

2. Nadzwyczaj ciekawa jest w tym kontekście Lyr. IV 28 (Do Mądrości Bożej. Gdy z Niemiec, Francji i Wtoch nadchodzity wieści o nowych wojnach). Adresat to Mądrość Boża, zatem Logos-Chrystus. Oda, parafrazująca fraszkę I $101 \mathrm{~J}$. Kochanowskiego (O żywocie ludzkim), przywołuje topikę Dei ridentis: bóstwa patrzącego z dystansu na poczynania śmiertelnych. Sarbiewski poszerza ją o nowe treści i sprawia, że gra z tradycją literacką staje się bardziej złożona. Dla Kochanowskiego pogoń za dobrami tego świata była czymś dziecinnym. Autor Lechiady idzie tym tropem, choć ma na myśli głównie wojnę jako narzędzie walki o władzę. Zastosowaną przez czarnoleskiego poetę metaforę odnosi do antycznego kontekstu - zabawy chłopców uganiających się za rzuconymi orzechami. W finale ody, gdy już widać na pewno, że ta niebezpieczna zabawa jest walką o władzę, czyli o berło, świat nabiera cech zredukowanych do wielkości punktu - piłki, którą usiłują rozszarpać wielcy tego świata. To myśl Seneki (O zjawiskach natury, I 9, 8, 11) ${ }^{16}$. Poeta patrzy na te wojenne zabawy z humanistycznym dystansem, co nie wyklucza emocjonalnego stosunku do losów orbis Christiani, traktowanego tu jako przestrzeń „domu”. Potwierdza to fragment (późniejszego o parę lat niż oda) listu poety do biskupa Stanisława Eubieńskiego:

Zazwyczaj gardzę tymi igraszkami ludzkimi, gardzę nimi w części duszy zwróconej ku sprawom Boskim i wiekuistym, i śmieję się w swym kąciku. Lecz w tak wielkim i tak niespodzianym spustoszeniu chrześcijańskiej rzeczypospolitej [podkr. E. B.] wielce jestem strapiony ${ }^{17}$.

\footnotetext{
${ }^{16}$ Zob. E. Buszewicz, Maciej Kazimierz Sarbieuski - Ody refleksyjne i religijne, w: Lektury polonistyczne. Średniowiecze — renesans - barok, t. 3, red.J. S. Gruchała, Kraków 1999, s. 128-130; M. K. Sarbiewski, O poincie i dowcipie, w: idem, Wykłady poetyki (Praecepta poetica), tł. i opr. S. Skimina, Wrocław 1958 (BPP B 5), s. 12-13.

${ }^{17}$ List 49. z Warszawy, 12 lutego 1638 roku, cyt. za: Korespondencja Macieja Kazimierza Sarbiewskiego ze Stanistawem
} 
3. Warto może dodać, że ta wyniszczająca zabawa w wojnę przeradza się niekiedy pod piórem Sarbiewskiego w krwawy teatr na scenie świata, reżyserowany przez Libitynę, mającą tu zarazem atrybuty śmierci i Niezgody: w serię wizji o charakterze niemal apokaliptycznym, nacechowanych tragiczną wizją świata, odpowiadającą siedemnastowiecznemu pojmowaniu tragedii jako ciągu przesuwających się obrazów ${ }^{18}$. Przykład mamy w odzie E rebus humanis excessus (Lyr. II 5):

$$
\begin{aligned}
& \text { A świat coraz to nowy skuteczny bój } \\
& \text { Na własną zgubę toczy. Bogini-Śmierć } \\
& \text { Dokarmia okrwawioną scenę } \\
& \text { Kłótnią i sporem, zniszczeniem, wojną, }
\end{aligned}
$$

Aż dzień ostatni zamknie ten teatr pod

Kopułą nieba (...).

$$
\text { (w. 65-70, tł. E. B.) }
$$

\section{Sarmacki Horacy o sarmackim rycerzu}

1. W europejsko-chrześcijańskiej świadomości poety z Sarbiewa mieści się równiė̇ przestrzeń sarmacka, która, jakkolwiek rozpoznana już badawczo ${ }^{19}$, wciąż stanowi zagadnienie dosyć otwarte. Zwrócimy tu uwagę na kilka „miejsc sarmackich”, odnoszących się zwłaszcza do spraw rycerskiego etosu. Chodzi tu zwłaszcza o uwydatnienie takich miejsc, gdzie retoryka spotyka się $z$ mitem, a tradycja antyczna $z$ rodzimą.

2. Na szczególną uwagę zasługują dwa wiersze, z tradycją rodzimą związane w sposób szczególny: Lyr. IV 5 i Lyr. IV6. Aby upamiętnić stłumienie przez Stanisława Koniecpolskiego powstania Tarasa Fedorowicza na Ukrainie, wpisuje je poeta w kontekst walk z Tatarami na Podolu. Odsyła zatem do pieśni Kochanowskiego o spustoszeniu Podola przez Tatarów, aby dokonać „palinodii” — odwołania lamentacji nad Podolem złupionym przez „pohańca sprosnego”. W tym celu najpierw prowadzi utwór Kochanowskiego ad fontes, czyli przekłada go na język horacjańskiej ody (Turcy stają się „Trakami”, Tatarzy „Gelonami”, Dniestr „Tyra”, a Krym „Taurydą”), aby powstała „parodia” (Lyr. IV 5). Następnie za jej pośrednictwem dokonuje „palinodii do parodii” (Lyr. IV 6), aby wyeksponować cały horacjanizm tekstu i wszystkie gry literackie. W ten sposób tradycja wojen sarmackich zostaje wprowadzona w przestrzeń antycznej i chrześcijańskiej Latinitatis.

Eubieńskiem, tł. i opr. J. Starnawski, Warszawa 1986 (Silıa Medii et Recentioris Aevii, t. 11), s. 168-171 (tckst polski), s. 64-66 (tekst łaciński).

${ }_{18} \mathrm{Tak}$ (w związku z silnym oddziaływaniem Seneki) widział tragedic na przykład holenderski pocta i dramaturg Joost van den Vondel (1587-1679), autor między innymi Józefa w' Dothain, Lucyfera, Adama na wygnaniu. Twórczość ta w nicwiclkim stopniu jest u nas znana; w ostatnich latach zajął sic̨ nią Piotr Oczko. O tragiczncj wizji świata w XVII wicku zob. J. Abramowska, O szesnastowiecznych koncepcjach tragizmu, w: cadem, Powtórzenia i wybory. Studia z termatologii i poetyki historycznej, Poznań 1995, s. 201-202; por. też L. Goldmann, Le Dieu caché. Études sur la vision tragique dans les „Pensées” de Pascal et dans le thêâtre de Racine, Paris 1955.

19 Zob. A. Borowski, O świadoności europejskiej Macieja Kazimierza Sarbiewskiego, op. cit., s. 191-202. 
3. Innym sposobem dokonywania takiego liaison może być połączenie tradycji antycznej z rodzimą emblematyką herbową. Widzimy to w $L y r$. IV 16 , odzie adresowanej do rycerstwa polskiego. Ma ona charakter pobudki, a obrazowaniem nawiązuje silnie do c. IV 4 Qualem ministrum fulminis alitem Horacjusza, z jej znamienną sentencją: fortes creantur fortibus et bonis (w. 29), upowszechnioną zresztą w literaturze polskiej od XVI wieku ${ }^{20}$. Sarbiewski stoi na straży takiej ciągłości, odwołując się do pamięci Lecha i Bolesława Chrobrego. Przypomina też znane ze wspomnianej ody alegorie-emblematy dzielności, czyli obrazy lwa i orła:

Nas czy kunsztownie na tarczy wyryty

Śmiałego obraz lwa próżno kryć będzie?

Daremnie orłów będziemy na tarczy

I zwinnych nosić jastrzębi znamiona,

Gdy, skoro gęstych strzał chmura zawarczy,

Osłabnie ręka, pierś zadrży zlękniona!

(w. 31-36, TK 357, 359)

Emblematyka lwa i orła, odwołująca się wyraźnie do ornamentyki heraldycznej, użyta tu w konwencji vituperatio czy przynajmniej admonitio, znalazła też u Sarbiewskiego gdzie indziej w epigramatach — zastosowanie laudacyjne, o czym również należy tutaj pamiętać ${ }^{21}$. Lew i orzeł składają się razem na wizerunek gryfa, który znajdował się na tarczy herbowej Jana Karola Chodkiewicza, wojownika par excellence, przywódcy spod Chocimia.

4. Wypada też przyjrzeć się od tej strony najsłynniejszej chyba spośród ód sławiących słynną bitwę z 1621 roku. Mowa o Lyr. IV 4, wprowadzającej fikcję liryczną w postaci śpiewu mołdawskiego rolnika Galeza, który w dobie pokoju, gdy lemiesze zastępują miecze:

Oraniu ujrzał, zadziwiony szczerze,

...po długiem

$\mathrm{Na}$ dackim polu wydobyte pługiem

Szyszaki mężów rdzawe i puklerze

I stosy kości, zbielałych na poły.

(w. 1-5, TK 311)

${ }^{20}$ Zob. np.: M. Sçp-Szarzyński, Pieśn IIII. O cnocie slacheckiej, w. 1-4:

Zacni się rodzą z zacnych i cnotliwych:

Znać w koniach sztuki ojczystc; lękliwych

Mężna orlica gotębi nic rodzi

Ani mdły zając z dużych lwów pochodzi.

(cyt. za: I w odmianach czasu smak jest. Antologia polskiej poezji epoki baroku, opr. J. Sokołowska, Warszawa 1991, s. 61).

${ }_{21}$ Wiele jest epigramatów Sarbiewskiego rozważających i rozpisujących na rozmaite konccpty herb Chodkicwicza, między innymi Ep: LXXXVIII, LXXXIX, XCVII, CXX, CXXVIII-CXLIII (zob. M. C. Sarbicwski, Poemata omnia, opr. T. Walla, Staraviesiae 1892, s. 465, 468-469, 478, 481-487); por. np. Ep CXXXIII:

Quadrupedum leo rex, aquila est regina volucrum:

Gryps, utrumque tibi spondet uterque decus (...)

(w. 1-2; s. 483). 
Wybiega poeta w przyszłość, ale niezbyt odległa, skoro oracz ów pamięta przebieg walki i może przedstawić go, niczym natchniony lirnik, we własnej „improwizacji”, jako że „w pokoju miło wspominać czas przeszłego boju”. Rzeź Turków przedstawiona jest na modłę horacjańską, ale zwraca uwagę wykorzystanie obrazów i sformułowań wenuzyjskiego wieszcza, a także motywów czarnoleskich $^{22}$ dla tematyki sarmackiej: połączone siły narodów szlacheckiej Rzeczypospolitej odpierają siły Półksiężyca. Na uwagę zasługują porównania odnoszące się do narodów Sarmacji: Polska i Litwa współdziałają w walce jak dwa pioruny, z różnych stron nacierające na chmurę, albo też jak dwie rzeki, siejące spustoszenie na polach wezbranymi nurtami. Nie pominięto również jednak ani Żmudzinów, ani mieszkańców Prus, ani Rusinów. Fikcyjny śpiewak kończy opowieść zgrabną formułą zakończenia - uznaje swoją Muzę za zbyt barbarzyńską, by zajmowała się rycerską pieśnią, pozostawiwszy więc tę ostatnią „późnym wnukom” (niektórzy pewnie dostrzegliby tu antycypację Wojny chocimskiej Wacława Potockiego), powraca z pługiem i wołkami do zagrody, bo nadchodzi wieczór. Skąd jednak w ogóle w inwencji Sarbiewskiego znalazł się oracz wydobywający z ziemi hełmy i kości poległych? Jest to obraz z pierwszej księgi Georgik Wergiliusza (w. 490-497), gdzie agricola spod Filippi rolniczymi narzędziami wydobyć ma z ziemi, po latach od słynnej bitwy, zardzewiałe pociski, hełmy, a także ogromne kości poległych. Patrzy więc zadziwiony na szczątki potęgi dawnych bohaterów (znów powraca tu topika starzejącego się świata i karlejących ludzi $\left.{ }^{23}\right)$. Z pewnością nie jest to jedyne spośród zupełnie niewystarczająco omówionych dotąd przywołań Georgik w liryce Sarbiewskiego ${ }^{24}$.

\section{Herkules i Parys, czyli o wzorcu i antywzorcu}

1. Parenetyczny ideał rycerza wyrażał się często poprzez chrześcijańską reinterpretację tradycji pogańskiej. Myślenie fabułami i skłonność do wyjaśniania kwestii teologicznych przy pomocy mitów antycznych to jedna z podstawowych cech osobowości twórczej Sarbiewskiego, widoczna zarówno $\mathrm{w}$ poezji, jak i w traktatach teoretycznych ${ }^{25}$. W utrwalaniu poetyckim takiego myślenia z pewnością wielce zaważyło oddziaływanie jezuickiej humanitatis, która, jak wnikliwie zauważył Andrzej Borowski, w wersji szkolnej, poprzez określoną ratio studiorum, umożliwiała pogodzenie dwóch sprzecznych ideowo postaw: aut Christianus — aut Horatianus — i przekształcenie tej trudnej alternatywy w:

...zhierarchizowaną, ale też zharmonizowaną parę pojęć wzorcowych. Wyrazić by ją można za pomocą formuły: magis Christianus quam Horatianus ${ }^{26}$.

\footnotetext{
22 Zob. np.: „Virtute pugnant, non numero, viri” — w przekładzie Karyłowskiego: „Mçstwem, nic liczbą, wojują mężowie" (w. 69, TK 315).

${ }^{23}$ Do tematologicznych filiacji złotego wieku zaliczył podobne obrazy (,'archeologiczny' motyw olbrzymich kości protoplastów, bliski opisom wielkiego i ciężkiego ich oręża, wyraźnie 'nie na miarę' dzisicjszych wątłych ludzi”) Dariusz Śnicżko, Mit wieku zlotego..., op. cit., s. 14.

${ }^{24}$ Intcresująca jest równicż w tym kontekścic Lyr. I23, z jej pochwałą „oracza” (na przykładzic Fabrycjusza) i pokazanicm przewagi trudu rolnika nad rzemiosłem rycerskim (z dość tu przewrotnym przykładem Jazona!).

25 Zob. J. Bolewski SJ, P. Kapusta SJ, M. C. Sarbiewski's Fabular Theology, w: Mathias Casimirus Sarbievius in cultura Lithuaniae, Poloniae, Europae..., opr. E. Ulcinaitë, Wilno 1998, s. 137-153; P. Urbański, Theologia fabulosa ..., op. cit., passim.

26 A. Borowski, O świadomości europejskiej Macieja Kazimierza Sarbiewskiego, op. cit., s. 202.
} 
Oznacza to w praktyce zastosowanie Horacjańskiego (i szerzej — starożytnego) imaginarium i słownika dla krzewienia wartości chrześcijańskich.

2. W myśl tych założeń wzorzec i antywzorzec wojownika odnosi się u Sarbiewskiego najczęściej do dwóch bohaterów mitycznych, od dawna zresztą w tradycji literackiej parenetycznie ważnych dzięki opowieściom podejmującym motyw rozstajnych dróg, gdzie Herakles jest przykładem słusznego, a Parys niesłusznego wyboru między vita activa a vita voluptaria. Wizerunek Parysa, niewskazany wprawdzie imiennie w tym kontekście przez poetę, lecz generujący się droga „odwróconej alegorezy”27 poprzez homerycko-horacjańskie (a zapośredniczone w naszej tradycji przez Kochanowskiego w Monomachiji Parysowej z Menelausem czy Odprawie postów greckich) obrazy wojownika o gładkiej twarzy, pięknowłosego, zniewieściałego i strojnego, jest antywzorcem i przedmiotem nagany, jak na przykład w Lyr. I 11, piętnującej przepych strojów rycerskich:

Walczyć trzeba nie złotem, nie

Brzękiem odznak. A więc nazbyt fałdzisty płaszcz,

Wstęgi, próżny klejnotów blask

Trzeba będzie wam już z ramion walecznych zdjąć.

Czemu cieszy się lekki hełm,

Gdy ulotną mu da godność przybranie z piór?

Czemu kitą potrząsa tak,

Jakby kłaniać się chciał drżącym Afrykom? A

Głowa po cóż jak trwożny ptak

Ma wyglądać, gdy gwizd wiatru, Zefiru żart

Lekkomyślnie ujawnia, że

Mygdońskiego tu ktoś ptaka pozbawił dóbr.

Już stalowy w powietrzu grad

Wisi i lekkich strzał gęsto lecących świst

Nad paradnym szyszakiem brzmi

Szable Medów już lśnią z dala jak nagły błysk

I Marsowy w nich ryczy grzmot.

Co odznaczeń da brzęk? Co da błyszczący hełm?

Kita, którą kołysze wiatr?

Albo tarcza, co lśni, pragnąc słonecznym dniom

Światła ująć w zazdrości swej?

Albo twarz, która zbyt chce, by ją widział ktoś?

Kołczan, co budzi pusty strach?

27 Zob. D. Śnieżko, Mit wieku złotego..., op. cit., s. 44: „W ciągu stuleci wykształcił się konwencjonalny klucz do deszyfracji mitów (...). Ten schemat w decydującym stopniu przyczynił się do ustanowicnia całego systemu personifikacji mitologicznych, a w konsekwencji ogólnego kodu o względnie ustabilizowanych relacjach pomiçdzy znaczącym a znaczonym, a zatem zdolnego do nazywania, klasyfikacji i wartościowania zjawisk i stanów rzcczy również spoza mitologicznego uniwersum. Dokonuje się wówczas operacja, którą można nazwać operacją odwróconej alegorezy: skoro bowiem na przykład imiç Parys konotuje wiarołomstwo, to i każdego wiarołomcę można nazwać Parysem (...); wiarołomstwo jest, jak wiadomo, tylko jedną z kulturowych cech Parysa: równie dobrze może on być antonomazją niezwykle urodziwego młodzieńca, czy nicfortunnego w swych wyrokach sçdzicgo". 
Z dłoni, co trzymać ma wodze, ty złoto rzuć;

Teraz trzeba żelaza, rąk,

Wielkich trzeba też dusz. Tylko to $z$ sobą miej (w. 1-26, tł. E. B.).

Warto nadmienić, że posiadająca długą tradycję topika „zbytku w strojach” bywała i w średniowieczu stosowana dla określenia etosu rycerskiego w ramach retoryki krucjaty. Przywołajmy tu porównawczo De laude nourae militiae Bernarda z Clairvaux:

Okrywacie jedwabiem wasze rumaki, a na zbroję wdziewacie (...) obwisłe szmatki. Pacykujecie wasze kopie, tarcze, siodła, okrywacie złotem, srebrem i kamykami uzdy i ostrogi. Potrzebnyż wam taki przepych, by ruszyć na spotkanie śmierci? (..) To rzeczy wojenne czy niewieście świecidełka? Czyżbyście mniemali, że miecz wroga uszanuje złoto, oszczędzi klejnoty, straci swą ostrość na jedwabiu? ${ }^{28}$

3. Pozytywną przeciwwagę takiego antywzorca może stanowić postać Hektora (widzimy to nawet w cytowanej wyżej odzie I 11, w. 55-59). Lepsze jednak możliwości dla chrześcijańskiej emulacji stwarza postać Heraklesa jako ideał nieustraszonego wojownika, prześcigniony przez nowych, katolickich Alcydów, których dokonania da się alegorycznie odnieść do prac antycznego herosa, a te wobec triumfu nowej religii muszą pozostać w cieniu. Tak ma się dokonać - w sensie metaforyczno-ideologicznym, a zarazem dosłownym, militarno-politycznym - przejęcie władzy nad Grecją. Oznacza to zarówno przewagę Christianitatis nad antiquitas, jak i nadzieję na uwolnienie greckich krain spod tureckiego jarzma. Znamiennym przykładem może być panegiryczna oda (Lyr. II 1), włączająca w taką parenezę cesarza Ferdynanda II, walczącego z popierającym Turków księciem siedmiogrodzkim:

Czyż jest królestwo albo też któraś z ziem

Odciętych morzem, czyż jest na wschodzie dom

Lub pod północnym gdzieś Wolarzem,

Gdzie by nikt brzmienia cesarskich triumfów

Nie słyszał? O, Cezarze, gdzie niesie wieść

Rydwanem, lśniącym kością słoniową kół

W'śód miast i ludów, tam cię znają,

A żeś wspanialszy nad Herkulesa

W swych czynach, płaczą mury wyniosłych Teb

I Hebros, wzdęty od Herkulesa chwal

Narzeka. Głuchy jęk wydały

Z siebie doliny Arkadii, bowiem

${ }^{28}$ Bernard z Clairvaux, op. cit, rozdz. 2 (De militia saeculari), s. 216; tł. pol. za: G. Minois, op. cit., s. 144. 
Tyś też powalił monstra niezwykłe, tak Zuchwalstwa pełne. Ciebie Alcydes sam

Uznaje godnym gór Nemei,

Argos i Idę podbitą tobie

Oddaje. On, choć karki straszliwym giął

Potworom, zdolnym ogniem i dymem tchnąć,

Choć strwożył piorunowym ciosem

Gadzie grzebienie i paszcze wielkie,

Choć przebył Nereusza lodową toń

I nieme morze o martwych brzegach, by

W tajemne wtargnąć kraje Styksu,

Gdzie lapał w sidła umarłych cienie

Ów łowca, który zdołał Orkusa zwieść

Bezlitosnego, wcześniej zaś skórę zdarł

Z szalejącego lwa i z byka,

I na jesionach Menalii wieszał;

Choć stoczył bitwy, godne, by wyryć je

Na złotym niebie, aby je czytać mógł

Z oddali Memnon i rumianej

Kraje Aurory, by podziwiano

Je na Zachodzie pośród wieczornych gwiazd,

Oddaje przecież tobie, Cezarze, laur

Triumfalny, wieniec $z$ topolowych

Liści i palmę należnej sławy

(w. 1-36, tł. E. B.).

Inne ody jednak potwierdzają swoistą dialektykę i tego mitu. „Smutny” humanizm ${ }^{29}$ Sarbiewskiego i dość typowe chyba dla jego czasów nastroje „schyłkowości” czy „zmierzchu” dziejów kreują, znaną między innymi z ód Horacego, wizję epoki rodzącej raczej karłów i potwory niż bohaterów:

Gdyby tak jakiś wiek Herkulesa nam chciał

Zrodzić, dosyć by był płodny. Lecz na ten świat

Częściej monstra chcą przyjšć: Gerion, Anteusz lub

Silny Giges o setce rąk.

W bezczynności trwa świat. Któżby ponaglił krok

Do wielkości chcąc mknąć? Małość zastąpić chce

29 Zob. A. Borowski, O świadomości europejskiej Macieja Kazimierza Sarbiewskiego, op. cit., s. 187. 
Dawną wielkość i tak sławy skarlały cień

Otrzymuje wyrodny wnuk.

$$
\text { (Lyr. II 4, w. 17-24, tł. E. B.) }
$$

\section{Wojna prywatna:}

\section{Miles Christianus wobec tradycji Ignacjańskiej i neostoickiej}

1. Musimy jeszcze wziąć pod uwagę kilka innych uwarunkowań, w świetle których retoryczne loci communes wojny są tak istotne w liryce Sarbiewskiego. Po pierwsze, będzie to tradycja Ignacjańska (z niebagatelnym przecież wpływem samej osobowości Loyoli, który jako były oficer chciał widzieć w swym zakonie „lekką kawalerię” gotową w każdej chwili do zwalczania przeciwnika ${ }^{30}$ ). Chodzi tu nie tyle o paramilitarną organizację Towarzystwa Jezusowego, co o powracające wielekroć w pismach Ignacego wezwanie do duchowej walki z wrogiem wewnętrznym, wyrażanej w słowach Vince te ipsum!

2. Maksyma ta nakłada się u Sarbiewskiego również na neostoicki imperatyw Seneki, wyrażony w sposób niemal bliźniaczy: Pugna te ipsum! W neostoickim ideale mędrca oprócz panowania nad sobą mieści się jednak również konieczność walki z Losem, ponieważ paktowanie z Fortuną oznaczałoby zaprzeczenie wewnętrznej niezależności i stałości:

Kostka. Rzut. Ślepy traf. Nie zaufam tej grze.

Nigdy nie rwie się dłoń, by uścisnął ją los,

By na zgodę, na kres cichych bojów i walk

Zawrzeć pokój i tak już trwać.

$$
\text { (Lyr. III 6, w. 1-4, tł. E. B.) }
$$

Scenerią wojny może być zatem nie tylko makro-, ale i mikrokosmos. Homo militans toczy wojnę również prywatnie. Miles Christianus walczył zwykle z szatanem, światem i ciałem. Sarbiewski chętniej przyznaje się do dziedzictwa Lucjusza Anneusza oraz św. Ignacego: pozostaje w konflikcie z Fortuną i ze swoim gorszym ,ja".

\section{Zamiast konkluzji}

1. Obraz wojny w liryce Macieja Kazimierza Sarbiewskiego wydaje się tak różnorodny, pełen wariantów i sprzeczności, ponieważ nakładają się tu na siebie różne przestrzenie topiczne, filtrowane przez trudne do jednoznacznego zdefiniowania - bez popadania w niebezpieczny psychologizm — zjawisko „osobowości literackiej”, ukształtowanej w wyniku określonej biografii intelektualno-duchowej, nie bez wpływu osobistych predylekcji i fascynacji. Wielką rolę odgrywa tu wyobraźnia mityczna (a przy niej przywiązanie do fabularnej teologii), ponadto świadomość europejska, czyli duchowa przestrzeń wyznaczona przez Latinitas i Christianitas — co wiąże się

30 Zob. J. Tazbir, Wstęp, w: idem, Literatura antyjezuicka $w$ Polsce 1578-1625, Warszawa 1963, s. 8. 
zarówno z ideą chrześcijańskiej, podporządkowanej papiestwu Europy, jak i z tradycją antyczną, W szczególności, choć nie tylko, horacjańską, przyswojoną w dużej mierze dzięki jezuickiej humanitas. Z europejską świadomością wiąże się swoisty sarmatyzm (obecny choćby w upowszechnianiu mitu antemurale, implikujący konieczność wojen z pogaństwem) i propagowanie wzoru rycerza, ale także poczucie jedności świata chrześcijańskiego (w którym wewnętrzne walki są czymś godnym potępienia). Dodajmy jeszcze smutek barokowego humanizmu, poczucie życia w epoce zmierzchu i tęsknotę za niebiańskim pokojem opromienionym pogodną wizją szeroko rozumianego Wieku Zlotego.

2. Wydaje się zresztą, że to bogactwo możliwości, z całą swą złożonością, paradoksami i kontrastami, wpisuje się dość typowo w powikłane antynomie miłości i wojny, zarysowane w dziejach chrześcijaństwa i Kościoła rzymskiego. Jak bowiem stwierdza w przedmowie do wydanej niedawno książki Georges Minois:

Studiowanie historii relacji Kościół - wojna nie sprowadza się do badania, czy Kościół był czynnikiem pokoju, czy też wojny, trzeba bowiem także znaleźć w duchowości chrześcijańskiej zarówno składniki sprzyjające wojennej agresywności, jak i intencje pacyfistyczne. Z tego punktu widzenia takie pojęcia jak zmaganie duchowe i krwawe męczeństwo są wyraźnie dwuznaczne, mogą bowiem prowadzić i do wysławiania świętej wojny, i do integralnego pacyfizmu. (...) Jeśli w toku swoich dziejów Kościól jawil się jako istota o dwóch obliczach, czy nie wynika to z faktu, że samo istnienie oznacza sprzeczność i dwuznaczność, dobro i zło, pokój i wojny? Już u narodzin chrześcijaństwa, w nauczaniu Chrystusa, widać tę niejednoznaczność, która przewija się przez całą historię aż do naszych dni, kiedy — bardziej niż kiedykolwiek — wojna i pokój wydają się nam nierozłączne, kiedy stanowią dwa oblicza tej samej zróżnicowanej, złożonej i pełnej sprzeczności ludzkości ${ }^{31}$. 